Reprod. Nutr. Dévelop., 1988, 28 (5), 1209-1216

\title{
On the role of epididymal factors in sperm fertility
}

J. A. BLAQUIER $\left({ }^{1}\right)\left({ }^{2}\right)$, M. S. CAMEO $\left({ }^{2}\right)$, P. S. CUASNICÚ $\left({ }^{1}\right)$, M. F. GONZALEZ ECHEVERRIA $\left({ }^{2}\right)$, L. PIÑEIRO $\left({ }^{1}\right)$, J. G. TEZÓN $\left({ }^{1}\right), M . H$. VAZQUEZ $\left({ }^{1}\right)$

(1) Instituto de Biologia y Medicina Experimental Obligado 2490, 1428 Buenos Aires, Argentina.

$\left({ }^{2}\right)$ Fertilab, Paraguay 2302

1121 Buenos Aires, Argentina.

Notwithstanding our improved descriptive knowledge of events occurring to mammalian sperm during epididymal maturation, the nature of the mechanisms involved in the development of such primary functions as forward motility (Bedford, 1975) and zona pellucida recognition (Saling, 1982) remain obscure. This review attempts to summarize the latest information produced by our laboratory in relation to the interaction of epididymal products with spermatozoa and the bearing that this interaction might have on sperm function.

Our interest has been primarily focused on androgen-induced secretory epididymal proteins that associate to sperm during epididymal transit and that our group has described in rats (Cameo and Blaquier, 1976), hamsters (Gonzalez Echeverría, Cuasnicú and Blaquier, 1982) and humans (Tezón et al., 1985b).

Immature hamster sperm, obtained from the proximal segments of the epididymis, were used as a model to induce in vitro modifications of their functions (Cuasnicú et al., 1984a). Exposure of these spermatozoa to a preparation enriched with androgen-induced secretory proteins EP2-EP3 (Gonzalez Echeverría, Cuasnicú and Blaquier, 1982) was able to induce a significant increase in homologous zona pellucida binding (Cuasnicú et al., 1984b). Since zona binding seemed to be one of the functions developed by sperm during epididymal transit (Cuasnicú et al., 1984a; Saling, 1982), our results were interpreted as reflecting the in vitro advancement of the maturational stage of these spermatozoa which was caused by the added epididymal preparation. Similarly, we were also able to show that immature sperm gained in fertilizing ability when pre-treated in vitro with the epididymal extract prior to in vivo or in vitro insemination (Gonzalez Echeverría et al., 1984).

Our latest results confirm these preliminary findings and support the role of epididymal proteins in sperm maturation. Briefly, our studies show that the preparation of the epididymal proteins mentioned above, in which EP2-EP3 represented $16 \%$ of the total protein, had a biological activity such that, on the average, treated sperm fertilized twice as many oocytes as their untreated controls 
(Gonzalez Echeverría et al., 1984). Further purification of the extract produced a fraction of epididymal proteins in which EP2-EP3 represented $60 \%$ of all the protein. When tested in our bioassay, this preparation was able to increase the fertilizing capacity of immature spermatozoa 7-fold at only half the dose of the former preparation (Blaquier et al., 1986). We can calculate that a 10 -fold purification of proteins EP2-EP3 from the $6 \%$ present in epididymal cytosol used as starting material, induced a 245 -fold increase in biological activity. These data are interpreted as showing not only the removal of an inhibitory factor present in the crude initial preparation, but also as pointing strongly to a role for EP2-EP3 in the development of fertilizing ability.

The active role of hamster epididymal proteins in the promotion of maturation is supported by recent results from Moore and Hartman (1986), showing that immature spermatozoa co-cultured with androgen-stimulated epididymal epithelium gain the ability to fertilize oocytes. In rats, Orgebin-Crist and FournierDelpech (1982) were able to demonstrate that incubation of immature sperm with a purified preparation of epididymal secretory proteins increased their zona pellucida binding ability.

From these and other data, a working hypothesis was formulated suggesting that epididymal glycoproteins added to sperm were responsible for at least part of the phenomena observed during maturation and led to the acquisition of fertilizing ability.

Since selective binding to the homologous zona pellucida seems to be the principal mechanism responsible for the species specificity of fertilization observed in mammals (Gwatkin, 1977) and the ability of sperm to recognize and bind to the homologous zona pellucida is developed during epididymal maturation (Cuasnicú et al., 1984a ; Saling, 1982), it follows that epididymal proteins which associate to sperm are likely to be part of the structure, being assembled on the sperm surface, which would enable interaction with the complementary site on the homologous zona or, perhaps, act as activators of its assembly or function.

This hypothesis requires that the added epididymal proteins be located on the external surface of the sperm plasma membrane and not be lost during the capacitation process when the sperm sheds many of its coating antigens (Johnson and Hunter, 1972).

Rat spermatozoa were used as a model for these studies mainly because rat androgen-induced epididymal secretory protein DE (Cameo and Blaquier, 1976) is available in a highly purified form (Garberi, Fontana and Blaquier, 1982), and a specific antibody has been developed for precise immunocytochemical studies.

Previous results had indicated that about $70 \%$ of the total protein DE associated with cauda epididymal spermatozoa was lost from the cells when these were capacitated for $4 \mathrm{~h}$ in utero (Kohane et al., 1980). However, the remaining $30 \%$ of protein DE seemed to have a relevent role in the fertilization process because the exposure of spermatozoa to the antibody, prior to in vivo insemination, markedly reduced the fertilization of oocytes ( $42 \%$ in controls and only $7 \%$ in the experimental group) (Cuasnicú et al., 1984c). 
Our most recent results concern the ultrastructural localization of protein DE in rat sperm and its fate during capacitation and after the induction of the acrosome reaction.

Using the sensitive peroxidase-antiperoxidase (PAP) immunocytochemical technique, we were able to show the localization of DE on the external surface of the sperm plasma membrane covering the head of the cell and its absence on the surface of the flagellum (Cameo et al., 1986). Capacitation was obtained by overnight incubation in $\mathrm{Ca}^{+}{ }^{+}$-free medium supplemented with bovine serum albumin, and synchronous acrosome reactions were induced by the addition of $\mathrm{CaCl}_{2}$. After this treatment, $58 \%$ of the cells had swollen acrosomes and $33 \%$ showed vesiculation of the plasma and outer acrosomal membranes, indicating the occurrence of the acrosome reaction. Immunocytochemical evidence of the presence of protein DE was seen in the vesicles covering the acrosomal region and also in the membrane of the postacrosomal region of the cell (Cameo et al., 1986).

These data are compatible with the postulated role of epididymal proteins in the sperm-zona pellucida recognition process since most authors agree that sperm bind to the homologous zona by the plasma membrane overlying the acrosome (Franklin, Barros and Russell, 1970; Moore and Bedford, 1983). However, the finding that some protein DE remains in the postacrosomal region after capacitation and the acrosome reaction allows some speculation about the different roles of this protein.

It is accepted that the postacrosomal region of the sperm plasma membrane is a specialized structure through which fusion with the oocyte membrane is started (Bedford and Cooper, 1978; Salgi and Phillips, 1980). In addition, it is also well established that a considerable degree of species specificity is retained by this step of membrane fusion in many mammals (Hanada and Chang, 1972). Therefore, one may speculate on the existence of a second species-specific site on the sperm membrane that would recognize its complementary structure on the homologous oolemma after the zona pellucida has been penetrated. Both the localization of protein DE on the postacrosomal region and the blocking effect of the specific antibody on fertilization (Cuasnicú et al., 1984c) support a possible role of the protein in this step of gamete interaction.

\section{Sperm maturation in man.}

The significant advances in our understanding of the mechanism of sperm maturation in laboratory animals achieved in the last few years contrasts with the scarcity of similar progress with respect to man. This may be attributed to the difficulty in obtaining suitable samples in adequate numbers and also to ethical limitations in the performance of experiments.

It was only after the description of the zona-free hamster oocyte penetration test by Yanagimachi et al. (1976) that the investigation of the existence of a functional sperm maturation process in the human epididymis became possible. In the first study in this field, Hinrichsen and Blaquier (1980) showed that sperm 
recovered from the cauda epididymis segment was able to penetrate $27 \%$ of the offered eggs, while sperm from the caput and corpus were unable to undergo the fusion process. These results were later confirmed by Moore, Hartman and Pryor (1983) who demonstrated that, while caput sperm were entirely unable to fuse with hamster oocytes, those cells recovered from the corpus and cauda segments penetrated 15 and $43 \%$ of the oocytes, respectively.

Since sperm maturation has been shown to be strictly androgen-dependent in all mammals (Orgebin-Crist, Danzo and Davies, 1976), a most useful primary approach to the identification of the factors involved in this process has been the analysis of androgen-induced secretory products of the organ that interact with the maturing spermatozoa.

To be able to study the influence of androgens on human epididymal function we adapted an organ culture system to human tissues that had originally been developed for rat and rabbit epididymides. Samples were obtained from patients undergoing castration as a treatment for prostatic carcinoma, and the tissues were cultured for periods up to 8 days (Tezón and Blaquier, 1981).

It was observed that once the cultured tissues were depleted of their endogenous androgen, the preparation, stimulated with $0.1 \mu \mathrm{M}$ of androgen (a concentration within the physiological range for this organ), responded by an increased synthesis of DNA and RNA (Tezón and Blaquier, 1981). This model was further characterized showing the presence of active $5 \alpha$-reduction of testosterone and the binding of androgen to specific intracellular receptors (Tezón et al., 1982).

We then attempted to determine whether some of the regulatory mechanisms of epididymal function such as the determination of the number of specific androgen binding sites within the epithelial cells (Tezón and Blaquier, 1983) and the activity of $5 \alpha$-reductase (de Larminat et al., 1978), known to be controlled by androgens in vivo in experimental animals, were also operating in cultured human tissues.

Our findings showed that the number of receptor sites seems to be controlled by androgens in cultured human epididymis since after 6 days in culture androgen-exposed tissues contained twice as many receptors sites as their controls (Vazquez, de Larminat and Blaquier, 1986).

Conversely, we could not demonstrate a clear-cut effect of androgen on the regulation of $5 \alpha$-reductase activity, notwithstanding the biochemical similarities between the epididymal enzyme in humans (de Larminat et al., 1980) and in experimental animals (de Larminat and Blaquier, 1978 ; Monsalve and Blaquier, 1977). Furthermore, our experiments explored (and eventually discarded) the existence of a possible masking effect of changes in NADPH concentration due to culture conditions and also established that most of the enzyme activity was associated with the epithelial cells during the culture period.

The system was applied to the study of androgen-induced secretory proteins of the human epididymis. After examination of the behaviour of 20 different samples, a pattern emerged showing the existence of 5 protein bands, separated by PAGE, whose synthesis was consistently stimulated by the addition of androgen to the culture media (Tezón et al., 1985b). The bands corresponded to 
molecular weights of $13900,21000,29000,38000$ and 69000 daltons and were produced by the caput and corpus regions of the organ. Initial evidence suggested that proteins with the same electrophoretic behaviour could be obtained after mild salt extraction of spermatozoa recovered from the cauda epididymis, while no equivalent band was obtained from sperm recovered from the caput region. These results suggested that the secretory proteins were loosely associated with spermatozoa during epididymal transit.

To explore this phenomenon further, a polyclonal antibody was raised against the fraction of ejaculated sperm antigens thought to be of epididymal origin (Tezón et al., 1985a). After purification by adsorption with semen from vasectomized donors, this antiserum reacted with cells of human epididymal epithelium while it failed to react with human prostate and testis. Furthermore, the antisera localized the antigens to the anterior portion of the head of epididymal spermatozoa (acrosomal cap) and a gradient of increasing intensity was observed in sperm cells from the successive segments (Tezón et al., 1985a). In contrast, the antibody failed to recognize spermatozoa recovered from the testis. In addition, the ability of the antiserum to precipitate androgen-induced radioactive proteins produced by the cultures supports our assumption of the identity between these proteins and those extracted from ejaculated sperm.

This antiserum became a useful tool to explore the possible biological significance of epididymal antigens in sperm function. In a recent report (Blaquier et al., 1987), we examined the content and distribution of antigens in ejaculated spermatozoa from fertile donors and infertile patients. The most relevent finding was that while $88 \%$ of all spermatozoa from the 18 fertile donors had the antigens localized on the acrosomal cap, $40 \%$ of our infertile patients showed a localization of antigens different from that in the controls. This was accompanied by a significant reduction in the amount of antigens present in their spermatozoa. These differences could not be correlated with parameters in the routine semen analysis.

These data led us to speculate that, if the human epididymal proteins present on the sperm surface played a role similar to that described in animals, their abnormal localization on spermatozoa from infertile patients might be related to their infertility because of the specificity of the region of the human sperm membrane which initiates fusion with the oocyte (Sathananthan and Chen, 1986).

Following a different experimental approach, we have also employed antiserum to investigate the fate of epididymal antigens during capacitation and attempted to correlate these findings with the percentage of fertilization of human oocytes in our IVF-ET program.

Aliquots of spermatozoa were obtained from each sample at different stages of capacitation: crude semen, after washing and swim-up, after incubation for $18 \mathrm{~h}$ at $37{ }^{\circ} \mathrm{C}$ in Ham's F-10 supplemented with $10 \%$ of maternal serum and, finally, from left-over media after incubation with the human oocyte in cumulus to obtain fertilization. In each sample we determined the proportion of cells in the population that were positively stained after indirect immunofluorescent labelling with our antiserum, as well as the localization of the antigens. 
Although preliminary, the results are suggestive of a pattern linking higher fertilizing ability with a faster loss of antigens from the sperm surface during capacitation. $37 \%$ of the spermatozoa of a subgroup of 6 men, who were able to fertilize more than $85 \%$ of their wives' oocytes, were intensely fluorescent after swim-up; only $9 \%$ of these spermatozoa had a stained acrosomal cap after overnight incubation with oocytes ( $76 \%$ reduction in sperm with epididymai antigens). In contrast, a group of 12 men, who fertilized less than $50 \%$ of the oocytes, presented $66 \%$ of fluorescent sperm after swim-up, $49 \%$ of which remained positive after attempted fertilization (26\% reduction in sperm with epididymal antigens).

This group of results suggests that epididymal antigens may behave like the acrosome stabilizing factors found in other species (Langlais and Roberts, 1985) ; they could be useful markers of capacitation in human sperm. Clearly, more research is needed to understand the role of epididymal factors in the development of sperm fertilizing ability.

$5^{e}$ Congrès de la Société d'Andrologie de langue française, Paris, décembre 1987.

Acknow/edgements. - This research was supported by the National Research Council of Argentina and by grant HD 15920 from the National Institute of Child Health and Human Development (USA).

\section{Résumé. Antigènes épididymaires et fertilité chez l'homme.}

Chez le rat et le hamster on a pu démontrer que quelques-unes des protéines produites par les cellules épididymaires, sous l'effet des androgènes sont liées aux spermatozoïdes ; ce revêtement des spermatozoïdes augmente leur capacité de reconnaître la zone pellucide et de féconder l'ovocyte. On peut proposer que ces protéines forment, sur la membrane cellulaire des spermatozoïdes, une région spécialisée pour la reconnaissance et l'adhésion à la zone pellucide.

Avec un système de culture organotypique des tubules épididymaires humains on a identifié après stimulation par des androgènes une sécrétion de protéines qui se lient aux spermatozoïdes. Des anticorps spécifiques pour ces protéines ont été utilisés pour étudier leur localisation et leur détermination quantitative dans les spermatozoïdes de donneurs fertiles et de patients stériles. Environ $30 \%$ des hommes stériles ont montré une altération de ces paramètres ; il pourrait exister une relation entre cette altération et leur stérilité.

Nous avons aussi étudié lors de la fécondation in vitro, le devenir de ces protéines pendant la capacitation du sperme. On a observé une corrélation entre la rapidité du détachement des protéines épididymaires de la surface des spermatozoïdes et leur fécondité.

On considère que ces résultats ont une importance expérimentale, mais aussi qu'ils peuvent être utilisés pour expliquer et peut-être améliorer quelques cas de stérilité.

\section{References}

BEDFORD J. M., 1975. Maturation, transport and fate of spermatozoa in the epididymis. In GREEP R. O., HAMILTON D. W. Handbook of Physiology, section 7, vol. 5, 303-317. Am. Physiol. Soc., Washington DC. 
BEDFORD J. M., COOPER G. W., 1978. Membrane fusion events in the fertilization of vertebrate eggs, 66-125. In POSTE G., NICHOLSON G. L. Cell surface reviews, vol. 5, Membrane fusion. Elsevier/North Holland Biomedical Press. Amsterdam.

BLAQUIER J. A., PIÑEIRO L., DAWIDOWSKI A., GONZALES-ECHEVERRIA F., 1986. Abstr. XII Congr. on Fertility and Fertility.

BLAQUIER J. A., CAMEO M. S., STEPHANY D., PIAZZA A., TEZON J., SHERINS R., 1987. Abnormal distribution of epididymal antigens on spermatozoa from infertile men. Fertil. Steril., 47, 302-309.

CAMEO M. S., BLAQUIER J. A., 1976. Androgen-controlled specific proteins in rat epididymis. J. Endocr., 69, 47-55.

CAMEO M. S., GONZALES-ECHEVERRIA F., BLAQUIER J. A., BURGOS M. H., 1986. Immunochemical localization of epididymal protein DE on rat spermatozoa. It's fate after induced acrosome reaction. Gamete Res., 15, 247-257.

CUASNICÚ P. S., GONZALES-ECHEVERRIA F., PIAZZA A., BLAQUIER J. A., 1984a. Addition of androgens to cultured hamster epididymis increases zona recognition by immature spermatozoa. J. Reprod. Fert., 70, 541-547.

CUASNICÚ P. S., GONZALES-ECHEVERRIA F., PIAZZA A., PIÑEIRO L., BLAQUIER J.A., 1984b. Epididymal proteins mimic the androgenic effect on zona pellucida recognition by immature hamster spermatozoa. J. Reprod. Fert., 71, 427-431.

CUASNICÚ P. S., GONZALES-ECHEVERRIA F., PIAZZA A., CAMEO M., BLAQUIER J.A., 1984c. Antibodies against epididymal glycoproteins block fertilizing ability in rat. $J$. Reprod. Fert., 72, 467-471.

DE LARMINAT M. A., BLAQUIER J. A., 1978. Androgen concentration and partial characterization of $5 \alpha$-reductase in the epididymis of the rhesus monkey. Steroids, 31, 129-138.

DE LARMINAT M. A., MONSALVE A., CHARREAU E., CALANDRA R., BLAQUIER J. A., 1978. Hormonal regulation of $5 \alpha$-reductase activity in rat epididymis. J. Endocr., 79. 157-165.

DE LARMINAT M. A., HINRICHSEN M., SCORTICATI C., GHIRHANDA J., BLAQUIER J. A., CALANDRA R., 1980. Uptake and metobilism of androgen by the human epididymis in vitro. J. Reprod. Fert., 59, 397-402.

FRANKLIN L. E., BARROS C., RUSSELL G. N., 1970. The acrosomal region and the acrosome reaction in sperm of the golden hamster. Biol. Reprod., 3, 180-200.

GARBERI J., FONTANA J., BLAQUIER J. A., 1982. Carbohydrate composition of specific rat epididymal protein. Int. J. Androl., 5, 619-626.

GONZALES-ECHEVERRÍA F., CUASNICÚ P., BLAQUIER J. A., 1982. Identification of androgendependent glycoproteins in the hamster epididymis and their association with spermatozoa. J. Reprod. Fert., 64, 1-7.

GONZALES-ECHEVERRIA F., CUASNICÚ P., PIAZZA A., PIÑEIRO L., BLAQUIER J. A., 1984. Addition of an androgen-free epididymal protein extract increases the ability of immature hamster spermatozoa to fertilize in vivo and in vitro. J. Reprod. Fert., 71, 433-437.

GWATKIN R. B. L., 1977. Fertilization mechanisms in man and mammals. Chapter 8. Attachement and binding of the sperm to the zona pellucida, 69-79. Plenum Press, New York.

HANADA A., CHANG M. C., 1972. Penetration of zona-free eggs by spermatozoa of different species. Biol. Reprod., 6, 300-309.

HINRICHSEN M., BLAQUIER J. A., 1980 . Evidence supporting the existence of sperm maturation in the human epididymis. J. Reprod. Fert., 60, 291-294.

JOHNSON W. L., HUNTER A. G., 1972. Seminal antigens: their alteration in the genital tract of female rabbits and during partial in vitro capacitation with beta amylase and beta glucuronidase. Biol. Reprod., 7, 332-340.

KOHANE A., GONZALES-ECHEVERRIA F., PIÑEIRO L., BLAQUIER J. A., 1980 . Interaction of proteins of epididymal origin with spermatozoa. Biol. Reprod., 23, 737-742.

LANGLAIS J., ROBERTS K., 1985. A molecular membrane model of sperm capacitation and the acrosome reaction of mammalian spermatozoa. Gamete Res., 12, 183-224.

MONSALVE A., BLAOUIER J. A., 1977 . Partial characterization of epididymal $5 \alpha$-reductase in the rat. Steroids, 30, $41-51$. 
MOORE H. D., BEDFORD M., 1983. The interaction of mammalian gametes in the female, 453-497. In HARTMANN J. F., Mechanism and control of animal fertilization. Acad. Press, New York.

MOORE H. D., HARTMAN T., PRYOR J., 1983. Development of the ovocyte-penetrating capacity of spermatozoa in the human epididymis. Int. J. Androl., 6, 310-318.

MOORE H. D., HARTMAN T., 1986. In vitro development of the fertilizing ability of hamster epididymal spermatozoa after co-culture with epithelium from the proximal cauda epididymidis. J. Reprod. Fert., 78, 347-352.

ORGEBIN-CRIST M. C., DANZO B., DAVIES J., 1975. Endocrine control of the development and maintenance of sperm fertilizing ability in the epididymis, 319-335. In GREEP R. O., HAMILTON D. W. Handbook of Physiology, section 7, vol. 5, Amer. Physiol. Soc., Washington.

ORGEBIN-CRIST M. C., FOURNIER-DELPECH S., 1982. Sperm-egg interaction. Evidence for maturational changes during epididymal transit. J. Androl., 3, 429-433.

SALING P., 1982. Development of the ability to bind to zonae pellucidae during epididymal maturation : reversible immobilization of mouse spermatozoa by Lanthanum. Biol. Reprod., 26, 429-436.

SATHANANTHAN H., CHEN C., 1980. Sperm-ovocyte membrane fusion in the human during monospermic fertilization. Gamete Res., 15, 177-186.

SHALGI R., PHILIPS D. M., 1980. Mechanics of sperm entry in cyclic hamster. J. U/trastruct. Res., 71, 154-161.

TEZÓN J. G., BLAQUIER J. A., 1981. The organ culture of human epididymal tubules and their response to androgens. Mol. cell. Endocr., 21, 233-242.

TEZÓN J. G., CUASNICÚ P. S., SCORTICATI C., BLAQUIER J. A., 1982. Development and characterisation of a model system for the study of epididymal physiology in man, 251-275. In DE NICOLA A. F., BLAQUIER J. A., Physiopathology of hypophysiol disturbances and diseases of reproduction. Alan R. Liss, New York.

TEZÓN J. G., BLAQUIER J. A., 1983. Androgens control androgen-binding sites in rat epididymis. Endocrinology, 113, 1025-1030.

TEZÓN J., RAMELLA E., CAMEO M., VASQUEZ M., BLAQUIER J. A., 1985a. Immunochemical localization of secretory antigens in the human epididymis and their association with spermatozoa. Biol. Reprod., 32, $591-597$.

TEZÓN J., VASOUEZ M., PIÑEIRO L., DE LARMINAT M. A., BLAQUIER J. A., 1985b. Identification of androgen induced proteins in human epididymis. Biol. Reprod., 32, 584-590.

VASQUEZ M., DE LARMINAT M. A., BLAQUIER J. A., 1986. Effect of androgen on androgen receptors in cultured human epididymis. J. Endocr., 111, 343-348.

YANAGIMACHI R., YANAGIMACHI H., ROGERS B. J., 1976. The use of zona-free animal ova as a test-system for the assessment of the fertilizing capacity of human spermatozoa. Biol. Reprod., 15, 471-476. 